\title{
ASSESSMENTS ABOUT THE ENERGY EFFICIENCY OF PCM IN FRESH AIR-COOLING SYSTEMS IN DIFFERENT BUILDING TYPES
}

\author{
Octavian G. Pop*, Mugur C. Balan \\ Technical University of Cluj-Napoca, 400641, Romania. \\ * Octavian.POP@termo.utcluj.ro
}

\begin{abstract}
Energy efficient technologies are recommended in the building sector, as buildings have proven to be high energy consumers. With the increase in global warming air cooling systems are more energy demanding. To enhance the energy efficiency of air-cooling systems phase change materials are considered due to their capacity of storing high amounts of cold. This technology must be designed and operated according to the number of occupants, type of activity and schedule of the building. This study presents an investigation of PCM based active cooling in a building considered to be an office compound, school and hospital. The performance indicator COP was used to evaluate the efficiency. It was found that the enhanced system was most efficient for the office building $(\mathrm{COP}=7.40)$ and least efficient for the hospital building $(\mathrm{COP}=5.89)$. The enhanced system was also compared with a classic reference system.

Key words: Engineering, Buildings, PCM, Energy Efficiency, Latent Heat.
\end{abstract}

\section{Introduction}

The improvement of energy efficiency in buildings is a worldwide research topic, as buildings are accountable for $40 \%$ of the global energy consumption [1]. Phase change materials (PCM) have been considered as potential storage mediums in latent heat thermal energy storage (LHTES) [2-4]. LHTES stores the ambient cold available during the summer nights through solidification of the PCM. The energy consumption of the LHTES represents the electrical energy absorbed by the fan that circulates air through the mass of PCM. Considering the cyclic operation of the LHTES the automation of the PCM based cooling systems must be correlated to the working schedule of the building. The mass of required PCM greatly depends on the number of occupants in the building and the type of activity they undergo. Organic PCMs available on the market undergo phase change in a temperature range [5]. Mathematical models predicting the response of LHTES consisting of a packed bed of spheres filled with PCM have been developed [6-8]. The LHTES behavior in an office building has been analyzed in [9]. This study aims to extend the investigation by considering the building modeled in [9] and adapting it to operate as a school and a hospital building. An LHTES with rectangular parallelepiped package of spheres filled with PCM has been considered. The efficiency of the LHTES is estimated with a validated mathematical model correctly predicting the behavior of the PCM during phase change as presented in [9]. The energy efficiency is evaluated using the coefficient of performance (COP) as thermodynamic indicator.

\section{Material}

The studied building presented in figure 1, has the following dimensions: length $\mathrm{L}_{\text {Bld. }}=$ $36.65 \mathrm{~m}$, width: $\mathrm{W}_{\text {Bld. }}=35.45 \mathrm{~m}$, height $\mathrm{H}_{\text {Bld }}$ $=8 \mathrm{~m}$, total floor surface area: $\mathrm{S}_{\mathrm{f}, \mathrm{l}}=1299.45$ $\mathrm{m}^{2}$, total surface area of the walls: $\mathrm{S}_{\text {wall }}=$ $711.61 \mathrm{~m}^{2}$.

The exterior walls consist of a system comprised of autoclaved cellular concrete with the thickness of $300 \mathrm{~mm}$ and mineral wool insulation with the thickness of $100 \mathrm{~mm}$. The flat roof system is mainly comprised of a concrete layer with the thickness of $150 \mathrm{~mm}$ 
and mineral wool insulation with the thickness of $150 \mathrm{~mm}$. The thermal properties of these materials were taken from [10].

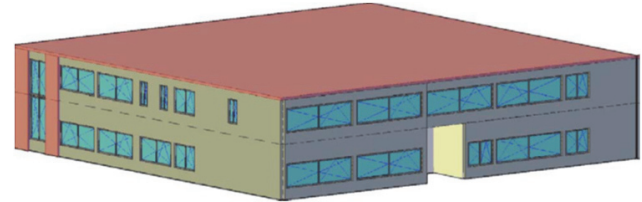

Figure 4. 3D model of the building

The total surface area of the windows is $\mathrm{S}_{\mathrm{win}}=439.60 \mathrm{~m}^{2}$. The windows consist of the following layers: 2 layers of argon with the thickness of $9 \mathrm{~mm}$ each confided within 3 layers of glass with a thickness of $4 \mathrm{~mm}$ each. The thermal properties for glass and argon were taken from [11].

In reference [9] the building was considered to be an office compound having the schedule, number of persons (n, [-]), specific required fresh air flow rate per person $\left(\dot{V}_{s a, p},\left[\mathrm{~m}^{3} / \mathrm{h} /\right.\right.$ pers. $\left.]\right)$ and per floor surface area $\left(\dot{V}_{s a, f},\left[\mathrm{~m}^{3} / \mathrm{h} / \mathrm{m}^{2}\right]\right)$ as presented in table 1 . In this study the building was considered to be a school building and a hospital building. The new operating conditions of the building are also presented in table 1 .

\begin{tabular}{ccccc}
$\begin{array}{c}\text { Building } \\
\text { type }\end{array}$ & $\begin{array}{c}\text { Schedule } \\
\text { Number } \\
\text { of } \\
\text { persons }\end{array}$ & $\begin{array}{c}\dot{V}_{s a, p} \\
{\left[\frac{m^{3} / h}{\text { pers }}\right]}\end{array}$ & {$\left[\begin{array}{c}\dot{V}_{s a, f} \\
m^{3} / h \\
m^{2}\end{array}\right]$} \\
\hline Office [9] 9: 0-17: 0 & 168 & 25 & 1.26 \\
School 8: 0-20: 0 & 344 & 25 & 1.26 \\
Hospital & $24 \mathrm{~h}$ & 100 & 36 & 3.60
\end{tabular}

Table 1. Schedule, number of persons and specific air flow rate.

The considered schedules were adapted to each building type. The specific air flow rates per person and floor surface area are the values recommended by [12] depending on the fresh air quality demand of each building type.

The building was considered located in Cluj-Napoca. The typical meteorological (TMY) year was used as climatic input data. The time period when cooling is needed is May to September [9].

\section{Method}

The first step in the evaluation is to determine the exterior heat inputs to the buildings during the hot season. The cooling load required to cover the heat input through the exterior walls has a steady component and a transient sinusoidal component that were calculated according to $[9,13]$.

The cooling load required to cover the heat input through the exterior windows has a component generated by heat inputs through exterior solar irradiance propagated through the glass and another component taking into account the heat input by global heat transfer through the glass and argon layers. In the confided space between two glass layers the heat transfer through natural convection between the argon layer and glass was assimilated with conduction according to [11]. The cooling load generated by the heat input from the exterior fresh air $\left(Q_{s, a}[\mathrm{~W}]\right)$ was determined with the following relation:

$$
\dot{Q}_{s, a}=\dot{V}_{s, a} \cdot\left(\rho_{s, a} \cdot c_{s, a}+\frac{\frac{x}{1000}}{\rho_{s, a}} \cdot c_{v}\right) \cdot\left(t_{e}-t_{s, a}\right)
$$

where: $\left(\dot{V}_{s, a},\left[\mathrm{~m}^{3} / \mathrm{h}\right]\right)$ is the volumetric supply air flow rate, $\rho_{\mathrm{s}, \mathrm{a}}\left[\mathrm{kg} / \mathrm{m}^{3}\right]$ is the density of the supply air, $\mathrm{c}_{\mathrm{s}, \mathrm{a}}=1.005 \mathrm{~kJ} / \mathrm{kg} \cdot \mathrm{K}$ is the specific heat capacity of the supply air, $x[\mathrm{~g} / \mathrm{kg}]$ is the absolute humidity, $\mathrm{c}_{\mathrm{v}}=1.875 \mathrm{~kJ} / \mathrm{kg} \cdot \mathrm{K}$ is the specific heat capacity of the water vapors, $\mathrm{t}_{\mathrm{e}}$ $\left[{ }^{\circ} \mathrm{C}\right]$ is the exterior air temperature from the TMY and $\mathrm{t}_{\mathrm{s}, \mathrm{a}}=22{ }^{\circ} \mathrm{C}$ is the temperature of the supply air.

The volumetric air flow rate was determined using the following relation with the data presented in table 1:

$$
\dot{V}_{s, a}=n \cdot \dot{V}_{s a, p}+S_{f, l} \cdot \dot{V}_{s a, f}
$$

The total cooling load is an important indicator that allows the estimation of the LHTES contribution to the cooling process of the building during the hot season.

The contribution of the LHTES to the reduction of energy consumption of the aircooling system has been investigated by considering the building equipped with a reference cooling system consisting of a fan, 
chiller and cooling coil and an enhanced system that ads a LHTES to the reference system. The LHTES alone is insufficient to cover the entirety of the fresh air-cooling load.

The electrical energy consumed by the compressor of the reference system was calculated based on a COP-temperature function [14]. The enhanced system with LHTES reduces the number of hours the compressor operates but requires electrical energy in order to operate the fan that assures circulation of air through the packed bed during both charging (solidification) and discharging (melting).

The pressure drop introduced by the packed bed was determined according to [15].

The COP of the reference fresh air cooling system was calculated for the entire hot season using the following relation:

$$
C O P_{r e f}=\frac{\sum Q_{s, a}}{\sum E_{c o m p}}
$$

where: $Q_{s, a}[\mathrm{kWh}]$ is the output thermal energy of the chiller required for the cooling of the fresh air, $E_{\text {comp }}[\mathrm{kWh}]$ is the electrical energy absorbed by the compressor.

The COP indicating the efficiency of the enhanced system with LHTES must take into account both the electrical energy consumed by the fan of the LHTES during both periods of charging and discharging and the electrical energy consumed by the compressor to cover the remainder of the fresh air cooling load in the periods of the summer day when the PCM mass is completely melted. The seasonal COP of the enhanced system was calculated with the following relation:

$$
C O P_{\text {enh }}=\frac{\sum Q_{s, a}}{\sum E_{\text {comp }}+\sum E_{f a n}}
$$

where: $E_{\text {fan }}[\mathrm{kWh}]$ is the electrical energy absorbed by the fan during both charging and discharging.

The latent heat thermal energy storage

The LHTES contains a packed bed of spherical capsules filled with PCM in a rectangular parallelepiped package as presented in figure 2.

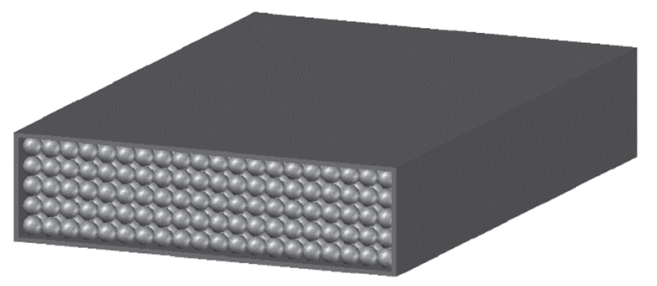

Figure 5. 3D model of the LHTES

The PCM considered for this study is RT20 a commercially available paraffin wax [5]. The thermal properties of RT20 were determined with differential scanning calorimetry (DSC) in [6].

As in the case of many organic compounds RT20 undergoes phase change within a temperature range. This range is identified in the DSC results which present the variation of heat flux released or absorbed by the PCM sample during solidification and melting. The peak temperature of the melting and solidification process of RT20 is in the vicinity of $20^{\circ} \mathrm{C}$ [6]. The peak phase change temperature of RT20 is suitable for the climatic conditions of Cluj-Napoca according to [9]. From the DSC results the variation of the apparent heat capacity with temperature of RT20 during phase change was determined [6]. The mathematical model used to simulate the efficiency of the LHTES is governed by the following equation:

$$
\begin{gathered}
\dot{m}_{s, a} \cdot c_{s, a} \cdot \Delta t_{a} \cdot d \tau= \\
=\left[m_{P C M, r} \cdot c_{a p p}\left(t_{P C M}\right)+m_{s p h} \cdot c_{s p h}\right] \cdot d t_{P C M}= \\
=\alpha \cdot S_{s p h} \cdot \Delta t_{a, P C M} \cdot d \tau
\end{gathered}
$$

where: $\dot{m}_{s, a}[\mathrm{~kg} / \mathrm{s}]$ is the mass air flow rate, $\mathrm{t}_{\mathrm{a}}$ $\left[{ }^{\circ} \mathrm{C}\right]$ is the air temperature at inlet, $\tau[\mathrm{s}]$ is the time, $\mathrm{m}_{\mathrm{PCM}}, \mathrm{r}[\mathrm{kg}]$ is the mass of PCM from a row of spheres, $m_{\text {sph }}[\mathrm{kg}]$ is the mass of the spherical capsules in this case polyethylene spheres, $c_{\text {sph }}[\mathrm{kJ} / \mathrm{kg} \cdot \mathrm{K}]$ is the specific heat capacity of the polyethylene sphere, $\mathrm{t}_{\mathrm{PCM}}$ is the temperature of the PCM, $\alpha\left[\mathrm{W} / \mathrm{m}^{2} \cdot \mathrm{K}\right]$ is the coefficient of forced convection, $\mathrm{S}_{\mathrm{sph}}\left[\mathrm{m}^{2}\right]$ is the outer surface of the sphere and $\Delta t_{a, P C M}$ $\left[{ }^{\circ} \mathrm{C}\right.$ or $\left.\mathrm{K}\right]$ is the mean logarithmic temperature difference between the PCM and air.

For simplicity the PCM temperature variation along the radius of the sphere was neglected. 
This model was validated and was found to accurately predict the air outlet temperature and PCM temperature from the LHTES in [9].

The mass of PCM ( $\mathrm{m}_{\mathrm{PCM}}[\mathrm{kg}]$ ) depends on the solidification possibility of the climatic conditions of Cluj-Napoca and on the supply airflow rate. The mass of PCM was determined with [9]:

$$
m_{P C M}=\frac{\dot{V}_{s, a} \cdot \rho_{s, a} \cdot c_{s, a} \cdot\left(t_{P C M e, s}-t_{e, \tau}\right)}{l_{P C M}}
$$

where: $\mathrm{t}_{\mathrm{PCMs}, \mathrm{e}}\left[{ }^{\circ} \mathrm{C}\right]$ is $\mathrm{PCM}$ solidification end temperature, $\mathrm{t}_{\mathrm{e}, \tau}\left[{ }^{\circ} \mathrm{C}\right]$ is the exterior air temperature at the moment $\tau$ and $1_{\mathrm{PCM}}[\mathrm{kJ} / \mathrm{kg}]$ is the latent heat of the PCM.

The mass of PCM was calculated for each type of building thus determining the size of each LHTES.

\section{Results and discussions}

The cooling load of the building was estimated considering the heat input through each element: walls (W), persons (P), equipment $(\mathrm{E})$, lighting $(\mathrm{L})$, windows $(\mathrm{G})$ and fresh supply air (F). The share of each component is presented in figures 3,4 and 5 for the office building, school and hospital respectively.

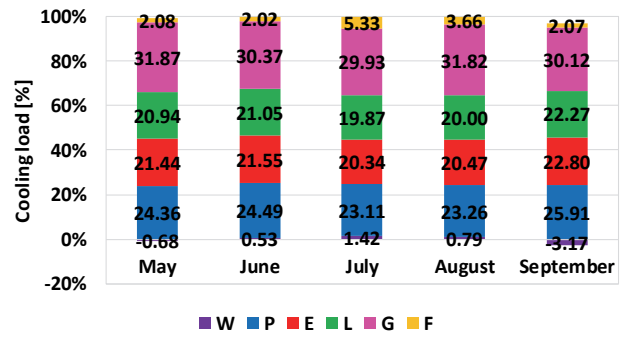

Figure 6. Share of each element to the cooling load - Office [9]

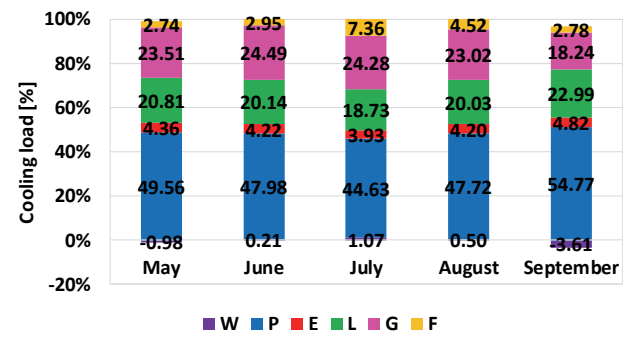

Figure 7. Share of each element to the cooling load - School, This study

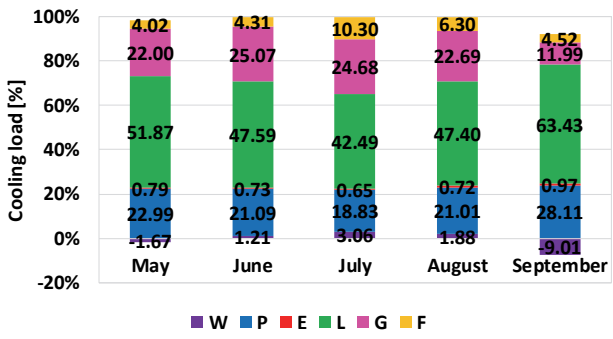

Figure 8. Share of each element to the cooling load - Hospital, This study

The maximum values of the cooling load for the office building, school and hospital are $130.4 \mathrm{kWh}, 155 \mathrm{kWh}$, and $120.7 \mathrm{kWh}$ respectively. The school has the highest cooling demand due to the high number of student. The hospital has the lowest number of occupants and despite the high demand on fresh air quality the hospital seems to require the lowest cooling load. This is mainly due to the low heat dissipated by the electrical equipment per person.

The LHTES in this study only covers the cooling of the fresh air. The maximum values of the cooling load for fresh supply air for the case of office building, school and hospital are $23.26 \mathrm{kWh}, 37.00 \mathrm{kWh}$, and $40.22 \mathrm{kWh}$ respectively. Despite the low number of occupants, the hospital requires important amounts of fresh air to satisfy the high demand on indoor comfort quality. Therefore, the highest thermal load needed for the cooling of fresh is in the case of the hospital building. The PCM mass and dimensions of LHTES (height/width $0.50 / 1.50 \mathrm{~m}$ ) are presented in table 2 .

Table 2. Results of the design process of the LHTES

\begin{tabular}{ccccc}
$\begin{array}{c}\text { Building } \\
\text { type }\end{array}$ & $\begin{array}{c}\text { Number of } \\
\text { LHTES }\end{array}$ & $\begin{array}{c}\text { Length } \\
{[\mathrm{m}]}\end{array}$ & $\begin{array}{c}\text { Pressure } \\
\text { drop/LHTES } \\
{[\mathrm{Pa}]}\end{array}$ & $\begin{array}{c}\text { Total } \\
\text { mass of } \\
\text { PCM [kg] }\end{array}$ \\
\hline Office [9] & 4 & 3.25 & 209 & 3095 \\
School & 6 & 3.45 & 256 & 4924 \\
Hospital & 6 & 3.70 & 324 & 5352
\end{tabular}

The contribution of the LHTES to the cooling of the exterior supply air during each month of the warm season is presented in figures 6,7 and 8 for the office building as evaluated in [9], school building and hospital building respectively. 


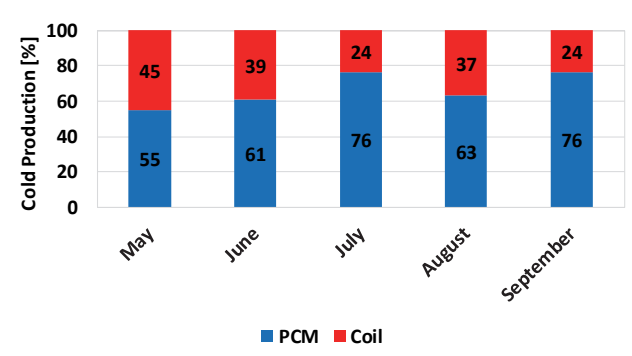

Figure 9. Contribution of LHTES to the fresh air-cooling load - Office [9]

Since the same sizing principle was implemented, the monthly contributions of the LHTES for each of the studied building types are similar. The contribution of the LHTES to the coverage of the total cooling load of the building is: $2.50 \%$ - office building, $3.16 \%$ - school and $4.50 \%$ hospital.

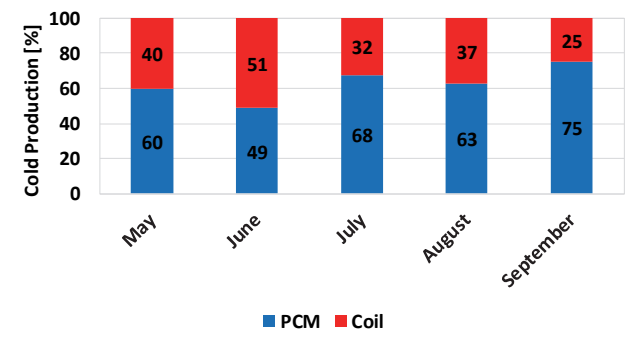

Figure 10. Contribution of LHTES to the fresh air-cooling load - School, This study

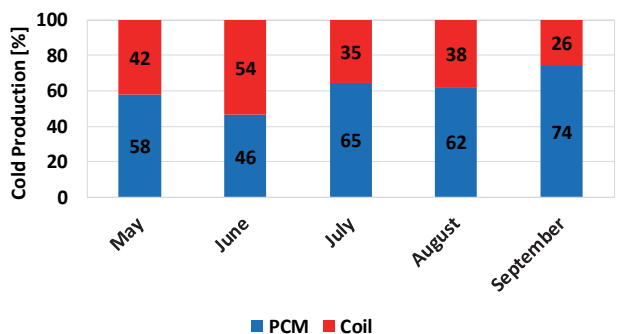

Figure 11. Contribution of LHTES to the fresh air cooling load - Hospital, This study

Due to the difference in PCM mass the electrical energy consumed by the fan depends on the pressure drop generated by the size of the packed bed. Figure 9 presents the reduction of energy consumption resulting from the LHTES enhanced system in comparison to the reference system.

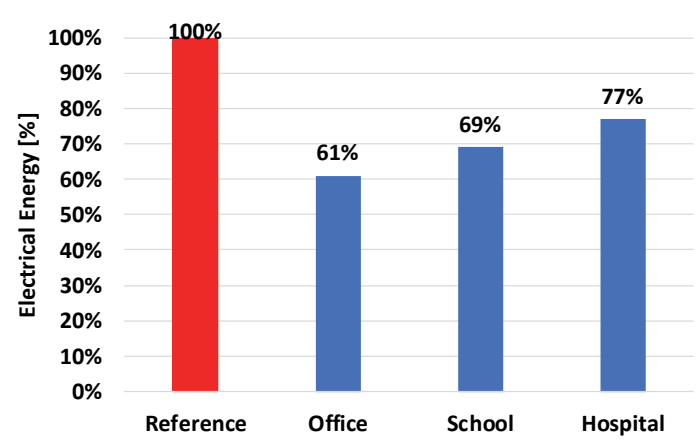

Figure 12. Comparative seasonal electrical energy consumption for the 3 cases

Figure 10 presents the COP values of the reference system (Ref.) and the LHTES enhanced system (Enh.) for all three cases.

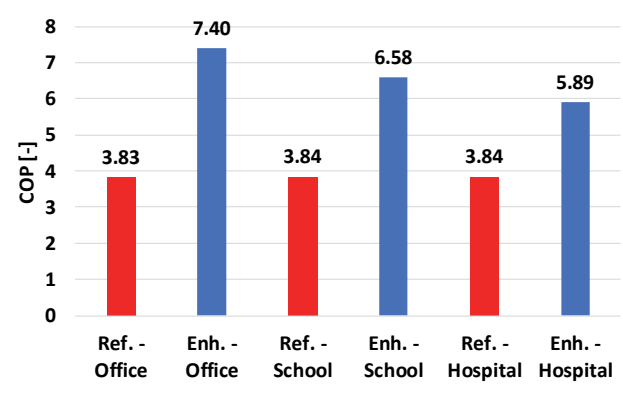

Figure 13. Comparative values of COP for the 3 cases

Figure 11 presents the increase in COP resulting from the integration of LHTES in the air-cooling system in comparison to the classical reference system for all three cases.

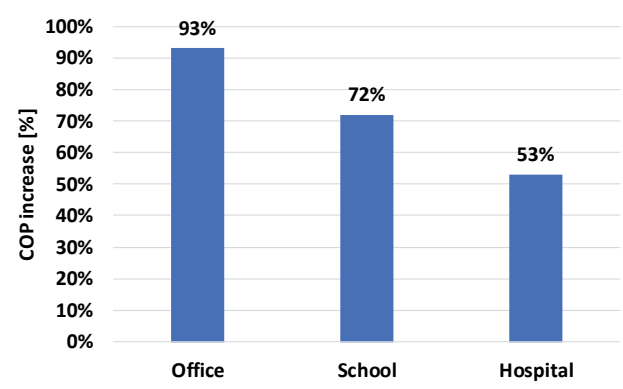

Figure 14. Comparison of COP increase

In the hospital building the LHTES operates at the lowest efficiency from the considered cases. In the case of the hospital the LHTES does not have a clearly defined 
charging and discharging schedule as the hospital operates 24h/7. Therefore, the LHTES switches from charging to discharging mode depending on the exterior air temperature. Hospitals however may require heating during the night due to the temperature swings as investigated in [16]. Thus, the hot air leaving the LHTES during charging can be used to ensure the comfort temperature in hospital rooms during the night.

The highest value of the COP increase was registered for the office building, having the lowest value of the fresh air-cooling load.

\section{Conclusions}

The efficiency of the LHTES technology was numerically investigated in a building considered to be an office building, school and hospital.

The cooling load for each type of building was calculated and compared. The contribution of the LHTES to the cooling of fresh air for each building type was determined. No significant differences were identified. There are however differences in energy efficiency. These differences are reflected in the COP values.

\section{Acknowledgement}

The results presented in this paper were obtained with the support of the Technical University of Cluj-Napoca through the research Contract no. 2013/12.07.2017, Internal Competition CICDI-2017.

\section{References}

Directive 2010/31/EU of the European Parliament and of the Council of 19 May 2010 on the energy performance of buildings 2010 . M. Alizadeh and S. M. Sadrameli, Development of freecooling based ventilation technology for buildings: Thermal energy storage (TES) unit, performance enhancement techniques and design considerations - A review, Renewable and Sustainable Energy Reviews 58, 2016, 619-645.

M. Iten, S. Liu, et al., A review on the airPCM-TES application for free cooling and heating in the buildings, Renewable and Sustainable Energy Reviews 61, 2016, 175.

F. Souayfane, F. Fardoun, et al., Phase
Change Materials (PCM) for cooling applications in buildings: A review, Energy and Buildings, 129, 2016, 396-431.

https: //www.rubitherm.eu/

C. Arkar and S. Medved, Influence of accuracy of thermal property data of a phase change material on the result of a numerical model of a packed bed latent heat storage with spheres, Thermochimica Acta, 2005, 438, 192-201.

E. Assis, L. Katsman, G. Ziskind and R. Letan, Numerical and experimental study of melting in a spherical shell, International Journal of Heat and Mass Transfer, 2007, 50, 1790-1804.

L. Xia, P. Zhang and R.Z.Wang, Numerical heat transfer analysis of the packed bed latent heat storage system based on an effective packed bed model. Energy, 2010. 35, p. 20222032.

O.G. Pop, L.F. Tutunaru, F. Bode, A.C. Abrudan, M.C. Balan, Energy efficiency of PCM integrated in fresh air-cooling systems in different climatic conditions, Applied Energy, 2018. 212, 976-996.

Normativ privind calculul termotehnic al elementelor de construcţie ale clădirilor, Indicativ C107-2005.

Popa B, Aradau D, Biris I, Iosifescu C, Madarasan T. et al., Manualul Inginerului Termotehnician, vol. I, Bucuresti, 1986.

Normativ pentru proiectarea, executarea si exploatarea instalatiilor de ventilare si climatizare, indicativ I5-2010.

STAS 6648/1-82, Instalaţii de ventilare şi climatizare, Calcul aporturilor de căldură din exterior prescripții fundamentale.

B. A. Porumb, M. C. Bălan and R.A. Boţu, Potential of indirect evaporative cooling to reduce the energy consumption in fresh air conditioning applications, Energy Procedia, 2016, 85C, 433-41.

I. E. Idelcik, Indrumător pentru calculul rezistenţelor hidraulice, Editura tehnică, Bucureşti, 1984.

O.G. Pop, A.C. Abrudan, D.S. Adace, A.G. Pocola and M.C. Balan, Potential of HVAC and solar technologies for hospital retrofit to reduce heating energy consumption, E3S Web Conferences, 2018, 32 